\title{
THE ROLE OF TECHNICAL AND NATURAL SCIENCES IN STONE MONUMENTS CARE
}

\author{
Katerina Kovarova1 and Eva Matouskova²
}

1. Czech Technical University, Faculty of Civil Engineering, Department of Geotechnics, Prague, Thákurova 7, Czech Republic; katerina.kovarova@fsv.cvut.cz

2. Czech Technical University, Faculty of Civil Engineering, Department of Geomatics, Prague, Thákurova 7, Czech Republic; eva.matouskova@fsv.cvut.cz

\begin{abstract}
Stone monuments maintenance requires the systematic approach which should be based on the cooperation among specialists through more branches, especially from humanities, natural and technical sciences. The main aim of this article is to present the benefit of the cooperation among geologists and civil engineers and share preliminary results of the Czech Ministry of Culture project DG20P02OVV021 "Stone surface topography and its application in stone element restoration field". Historic stone surfaces often contain stonemasons tool traces as an undoubtable part of historical monument value. The study and protection of the testimony of past is therefore very important. As a part of our project, we are conducting field and laboratory research of historic stone surfaces bearing the original tool traces. The studied area is the Prague urban conservation zone for its stone monuments richness from Romanesque to present days. First, the geological research of the stone masonry surface is conducted in the cooperation with archaeologists. The tool traces are documented, and the state of stone is described. Because of the negative influence of weathering processes on the stone durability, respectively tool traces, we decided to monitor the chosen historical stone surface using the hyperspectral analysis. Based on the analysis of the results we will be able to better understand the behaviour of stone surface and traces on it during the time.
\end{abstract}

\section{KEYWORDS}

Stone monuments, Tool traces, Weathering, Hyperspectral analysis, Prague

\section{INTRODUCTION}

A value of historical stone monument consists of many variables, including the traces of craftsmanship processing which should be taken into the attention during the conservation and restoration interventions. Stonemasons work traces are an integral part of the monument expression. Moreover, these traces help reveal working practices of old masters and the craft development over time. The above reasons explain the importance of studying and preserving traces of tools on the surfaces of historical buildings. The presented article is an extract of studies that systematically map the cutting work of stones in the territory of Prague from Romanesque time to the present day. Our work is based on a documentation and assessment of stone craftsman processing traces of historical buildings in the Prague urban conservation zone.

Stone monuments maintenance requires the systematic approach which should be based on the cooperation among specialist through more branches, especially from humanities, natural and technical sciences. Therefore, the main aim of this article is to present the benefit of the cooperation among geologists and civil engineers. If we talk about stone masonry maintenance and survey, first the building stone characterisation, including petrographic analysis and evaluation of degradation 
degree thanks to the weathering action, is necessary. Therefore, the involvement of an geologists is a logical and undoubtable step in a masonry survey.

The Prague urban conservation zone is rich for the monuments from natural stone. The use of natural stone was influenced by its resources and transport possibilities and technical development of its quarrying and processing. The sedimentary stones were widely used as a dimension stone of many monuments from Romanesque time to Baroque, whereas the magmatic stones, especially granites, have been used for these purposes in the architecture since $2^{\text {nd }}$ half of $19^{\text {th }}$ century. The main building stone of Romanesque time was predominantly opoka. Sandstones were mainly used as the dimension stone since Gothic period until the granitic stones were used instead. Another sedimentary stones, especially limestones, occurred in the Prague architecture in Gothic period, but its massive use together with marbles was mainly in Baroque. Due to a high demand for marble in this period, its resources were not sufficient and therefore artificial marble was widely used [1].

As any other building material, stones undergo to weathering processes and so are damaged. They lose their original qualitative properties, such as uniaxial compressive strength and durability. The presence of water in liquid state with dissolved chemical compounds is the most important factor controlling the durability of natural stone. For example, the ice and salt crystallization may cause the pressures from tens to hundreds MPa [2], what usually exceeds tensile strength of most stones. The relationship between frost and salt weathering is discussed by e.g., Williams and Robinson [3]. The damage rate depends on the salt combination applied in the salt weathering process. Crystallizing salts in stone pore space create a set of several processes acting together. Physical processes play the most important part [2], which may be accompanied with chemical processes and action of organisms [4]. This process may cause surface crumbling or delamination [2] and the tool traces are therefore damaged as well (see Figure 1).

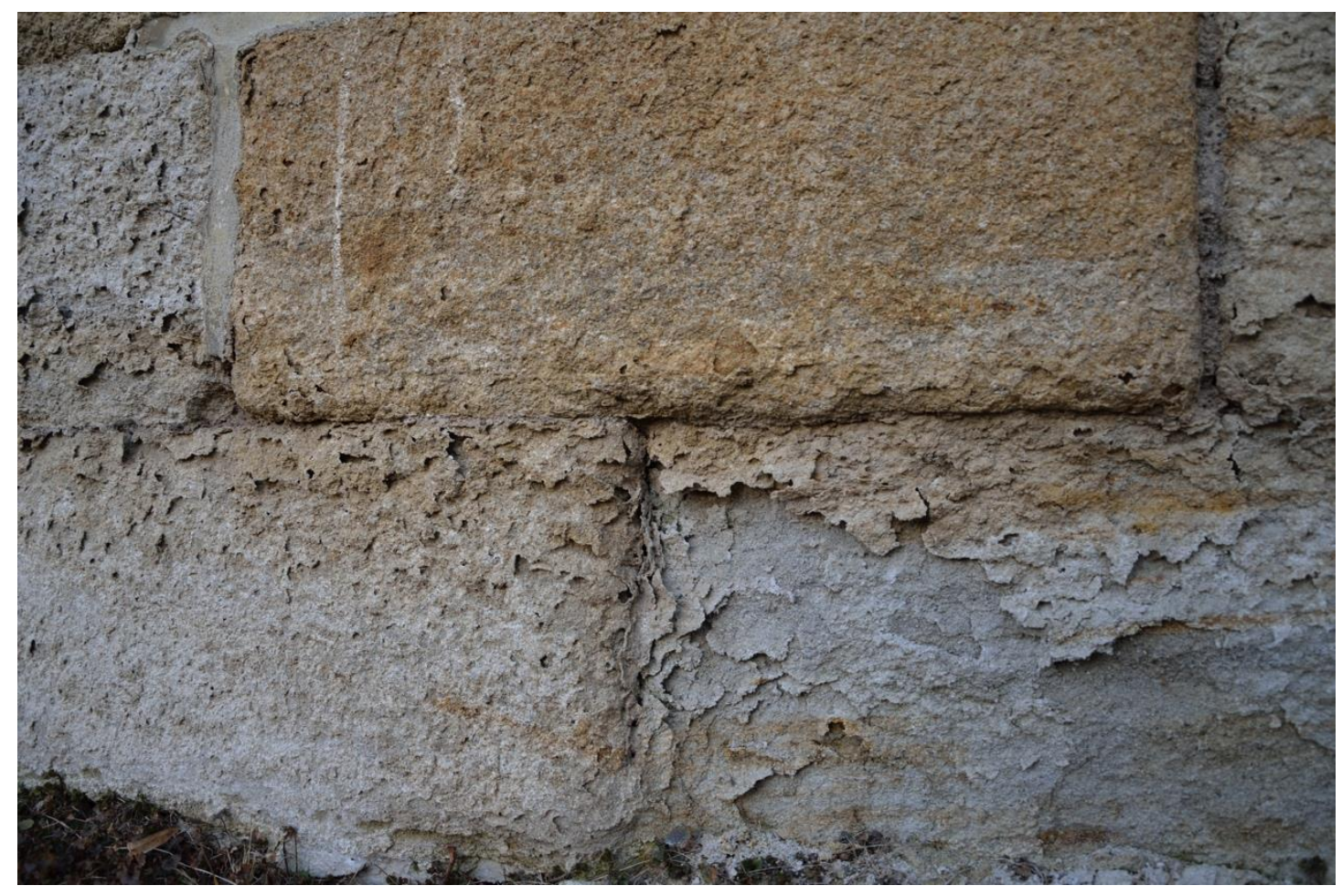

Fig. 1 - Blistering of sandstone surface with the subsequent surface scaling with strongly damaged tool traces, St. Jacob's Church, Srbeč.

The clastic sedimentary stones are the most sensitive to weathering agents from the wide range of used building stone. The reason is the arrangement of its internal structure, especially the 
abundant presence of interconnected pores. The way of their origin determines the character of their internal structure. The presence of water may also cause dissolution and leaching of binder and thus negatively influence the cohesion. To be able to better understand the behaviour of stone surface and traces on it during the time, we decided to monitor the chosen historical stone surface using the hyperspectral analysis.

\section{Hyperspectral imaging}

Hyperspectral imaging has been an area of active research and development in many different fields during past decades and its giant potential is getting more visible with technical development. Recently hyperspectral imaging data have started to be widely used among the public in a wide variety of applications. Different names were given to this field of study like hyperspectral imaging, imaging spectrometry, or imaging spectroscopy, but the output is similar - derive the set material's reflectance spectra in a given range. Unlike the multispectral sensor which operates in a relatively low number of wide spectral bands hyperspectral scanners give full information across the electromagnetic spectrum in given spectral range. This is done by collecting many (tens to hundreds) narrow, closely spaced spectral bands so that the resulting spectra appear to be continuous curves. Using these data one can enable the extraction of reflectance spectra at a pixel scale that can be directly compared with similar spectra measured in the field or in a laboratory. Although most hyperspectral sensors measure hundreds of wavelengths, it is not the number of measured wavelengths that define a sensor to be hyperspectral. It is rather the narrowness and contiguous nature of the measurements.

Soil weathering and alteration can be determined by various factors, where one can mention wind, sunlight and temperature as well as rain, snow, moisture and biological contamination. The first affects the stability of the rock matrix, while the second acts through chemical corrosion of the stone forming material. As we mentioned above, physical, chemical and biological agents act in coassociation to deteriorate a stone [5]. Biodeterioration is a situation when biological material settles on a construction stone(s) of a structure and evolves there. In this case, we often deal with algae, bacteria, moss, lichens and fungi. This work is an example of how a stone affected by biodeterioration can be hyperspectraly analysed.

Biological contamination is very common in sandstone and it is often created by a layer of algae together with dust particles, soot, fungi fibres and bacteria. This coating creates a slime on its lower part that contain small stone particles. During frost circles and with changing water to ice stone particles that are covered by algae are crumbled. The crust prevents the stone from "breathing", plugs plasters pores and contributes to the disintegration of the masonry surface. Expansivity of such crust in its drying out and damping is different than the expansivity of material. Similar crumbling can be seen when cyanobacterium growth is visible [6]. Biological contamination of stone - its development, minimization and treatment methods are investigated by various authors worldwide, for more information see [7-14].

\section{METHODS AND PROCEDURES}

For the purpose of the survey a hyperspectral monitoring of processed stone surface was conducted which is negatively influenced by weathering action. We chose the stone block of the Kř́žovnické náměstí retaining masonry (Figure 2) which is dated back to 1848 [15]. Generally, this ashlar masonry is predominantly built form fine to middle grained sandstone which shows more or less surface degradation signs. The chosen stone block is of sufficient size and contains more degradation manifestations like presence of organisms (e.g. moss and lichen), signs of water freezing/thawing and also salt weathering action, as it is obvious in Figure 4. Moreover, the selection of this stone block is also very useful for studying and understanding a weathering processes synergy, which do not occur separately, but often together. Additionally, the studied stone block is 


\section{$\prod_{\substack{\text { CIVIL } \\ \text { ENGINEERING }}}$ JOURNAL}

conveniently located near the Vltava River in the immediate vicinity of Charles Bridge and it is therefore influenced by its seasonal fluctuation.

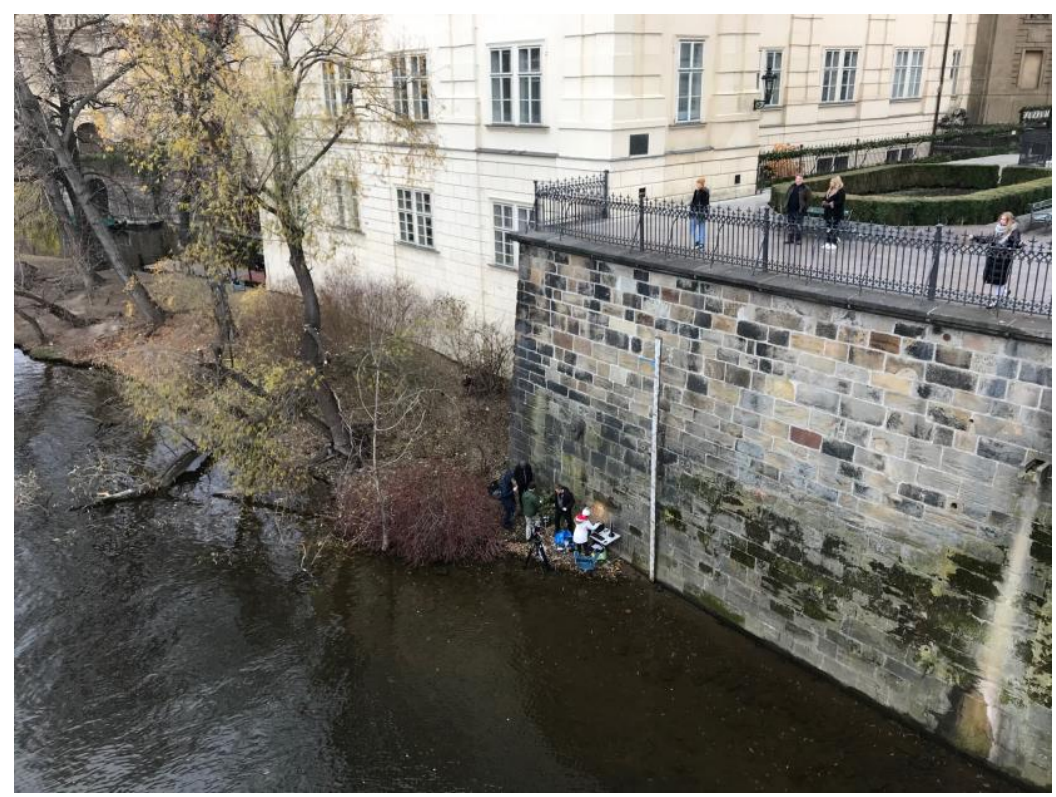

Fig. 2 - The location of a selected sandstone block in Kř́žovnické náměstí retaining masonry.

\section{Hyperspectral analysis}

For the purpose of hyperspectral analysis, a unique portable hyperspectral imaging device consisting of a hyperspectral sensor, Pan\&Tilt unit, tripod, illumination sources and a control unit was used. An A-series hyperspectral VNIR camera Hyperspec VNIR manufactured by Headwall Photonics Inc. [16] is used. Headwall Photonics' Hyperspec imaging spectrometer platform is built on a reflective concentric, $\mathrm{f} / 2$ optical design. The camera is lens-based, thus equipped with a CMount $35 \mathrm{~mm}$ objective and $18 \mathrm{~mm}$ long and $25 / 60$ um wide slit. The operational wavelength ranges between 400 to $1000 \mathrm{~nm}$ and the focal plane size is 1004 spatial and 810 spectral bands in this range. The setup (hyperspectral camera, Pan\&Tilt unit and the illumination platform) has been placed on a strong tripod Callidus CINE 2000 to enable one to move the system and adjust the height of the camera. Special tripod head had to be created for the Pan\&Tilt unit fitting. Control of the system is performed by the HDPU (Hyperspec Data Processing Unit) and using Hyperspec III. software developed by Headwall Photonics, Inc. Hyperspectral imaging data are commonly given in the form of a 3D data cube. The 3D data cube information resembles the reflectance spectrometer data - wavelength and a corresponding signal value. From this dataset, user can derive a spectral curve or to analyse and work with each band separately.

\section{Data gaining and processing}

In the second phase of the Czech Ministry of Culture project DG20P02OVV021 "Stone surface topography and its application in stone element restoration field" a historical sandstone sample was spectrally analysed in-situ to determine its biological contamination. For the specific object of interest temporal analysis is conducted. This paper shows preliminary results comparing summer (August 2021) and autumn (November 2021) results. The scanning distance of $2 \mathrm{~m}$ (see Figure 3) ensures that the object of interest (Figure 4) is scanned in one file and gives a pixel size of approximately $4 \mathrm{~mm}$. Each dataset was collected with Zenith reflectance targets to ensure quality calibration and repeatability. ENVI 5.5 software was used for preprocessing and analysing the data. 


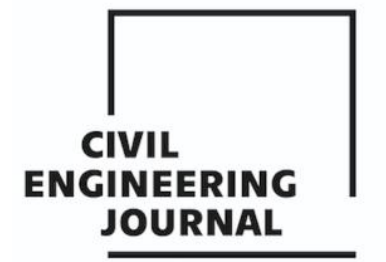

Article no. 70

THE CIVIL ENGINEERING JOURNAL 4-2021

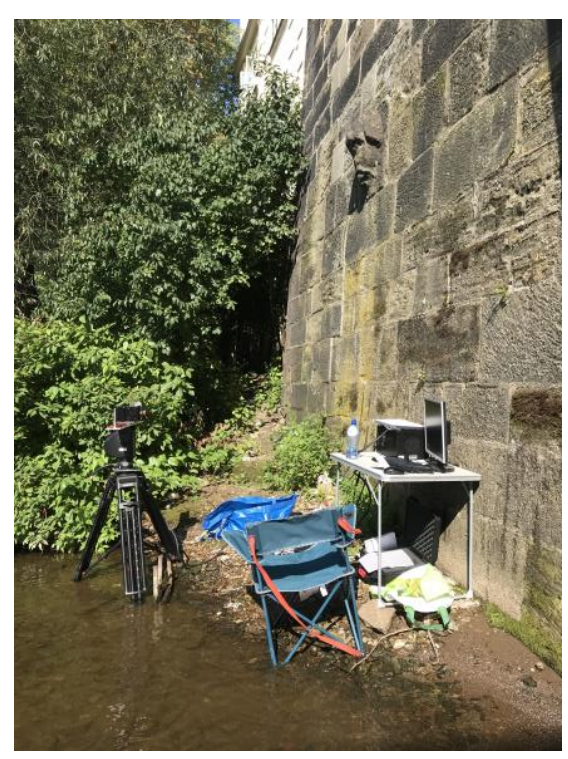

Fig. 3 - Measuring setup.

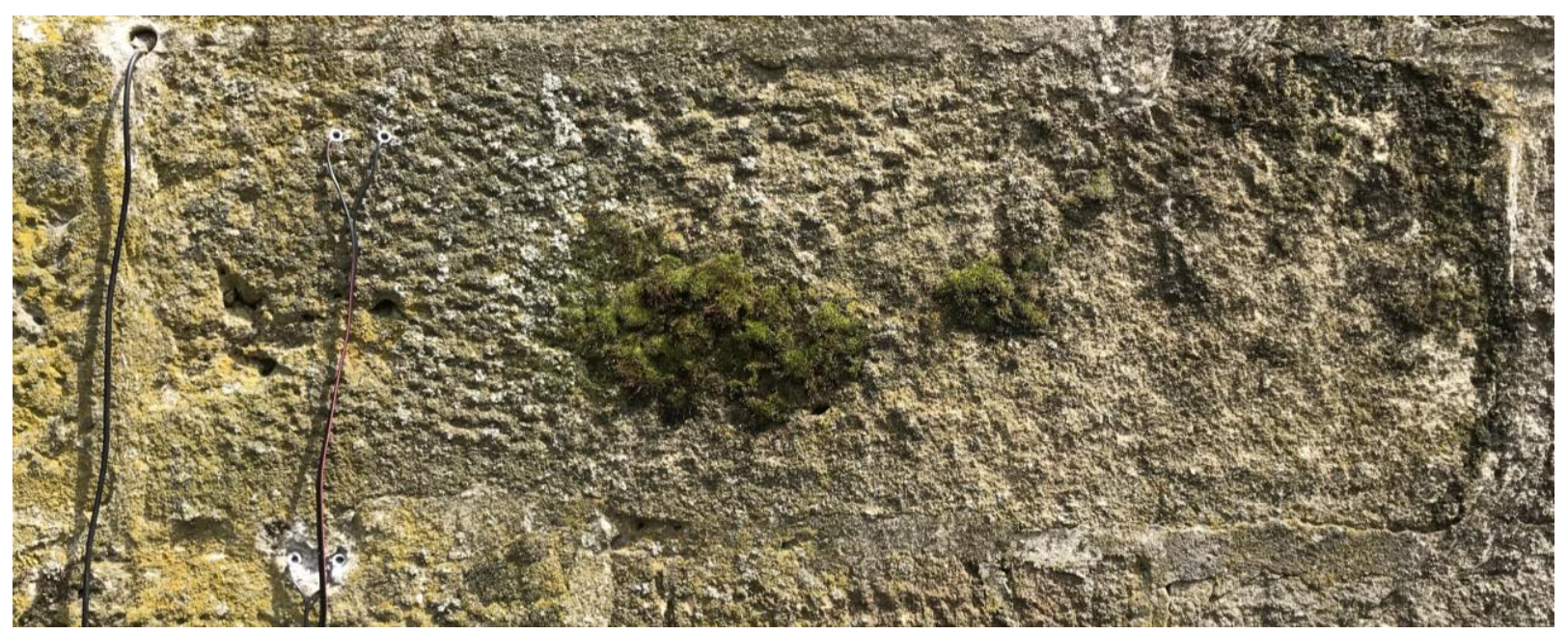

Fig. 4 - Area of interest photograph.

Gained data has to be registered, resized and recomputed in order to compare results from various times. To monitor biological contamination of stone Normalized Difference Vegetation Index (NDVI) [17] was used to show the difference between summer and autumn vegetation over. NDVI is one of the oldest, most well-known, and most frequently used vegetation index. The combination of its normalized difference formulation and use of the highest absorption and reflectance regions of chlorophyll make it robust over a wide range of conditions. It can, however, saturate in dense vegetation conditions when leaf area index (LAI) becomes high. $\mathrm{LAl}$ is calculated as half the area of all leaves per unit area of ground. NDVI is defined by the equation:

$$
\mathrm{NDVI}=(\mathrm{NIR}-\mathrm{RED}) /(\mathrm{NIR}+\mathrm{RED})
$$

The value of this index ranges from -1 to 1 . The common range for green vegetation is 0.2 to 0.8 , the denser the vegetation the higher NDVI value. NDVI is one of the broadband greenness vegetation indeces included into the ENVI 5.5. software. These VIs are designed to provide a measure of the overall amount and quality of photosynthetic material in vegetation, which is essential 
for understanding the state of vegetation for any purpose. Broadband greenness VIs compares reflectance measurements from the reflectance peak of vegetation in the near-infrared range to another measurement taken in the red range, where chlorophyll absorbs photons to store into energy through photosynthesis. Use of the near-infrared measurements, with much greater penetration depth through the canopy than red, allows sounding of the total amount of green vegetation in the column until the signal saturates at very high levels [18]. NDVI values are explained in Table 1.

Tab. 1 - NDVI value explanation table.

\begin{tabular}{|c|l|c|}
\hline NDVI & INTERPRETATION & COLOR \\
\hline$-1,0-0,0$ & Bare rock & Red \\
\hline $0,0-0,2$ & Bare rock / almost absent density & Sienna \\
\hline $0,2-0,4$ & Low density & Yellow \\
\hline $0,4-0,6$ & Medium density & Dark green \\
\hline $0,6-0,8$ & High density & Green1 \\
\hline $0,8-1,0$ & Very high density & Green2 \\
\hline
\end{tabular}

\section{RESULTS}

Figures 5 and 7 show graphs with NDVI values and corresponding values with a scale step of 0,2 . The first class (shown in red colour) covers negative NDVI values and therefore represents areas without any vegetation. Colours in resulting images (Figures 6 and 8) follow the graph legend. Mean spectral signatures of derived NDVI value classes are shown in Figure 9.

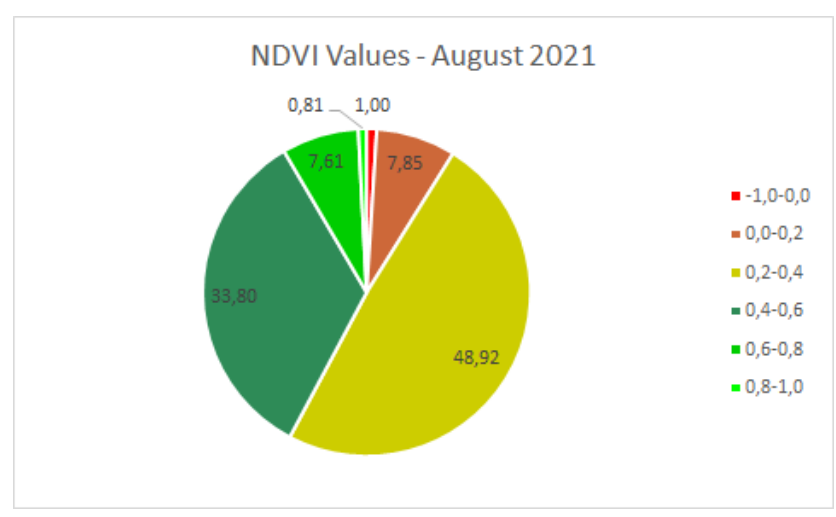

Fig. 5 - NDVI Values derived into 6 classes together with percentage of each class 


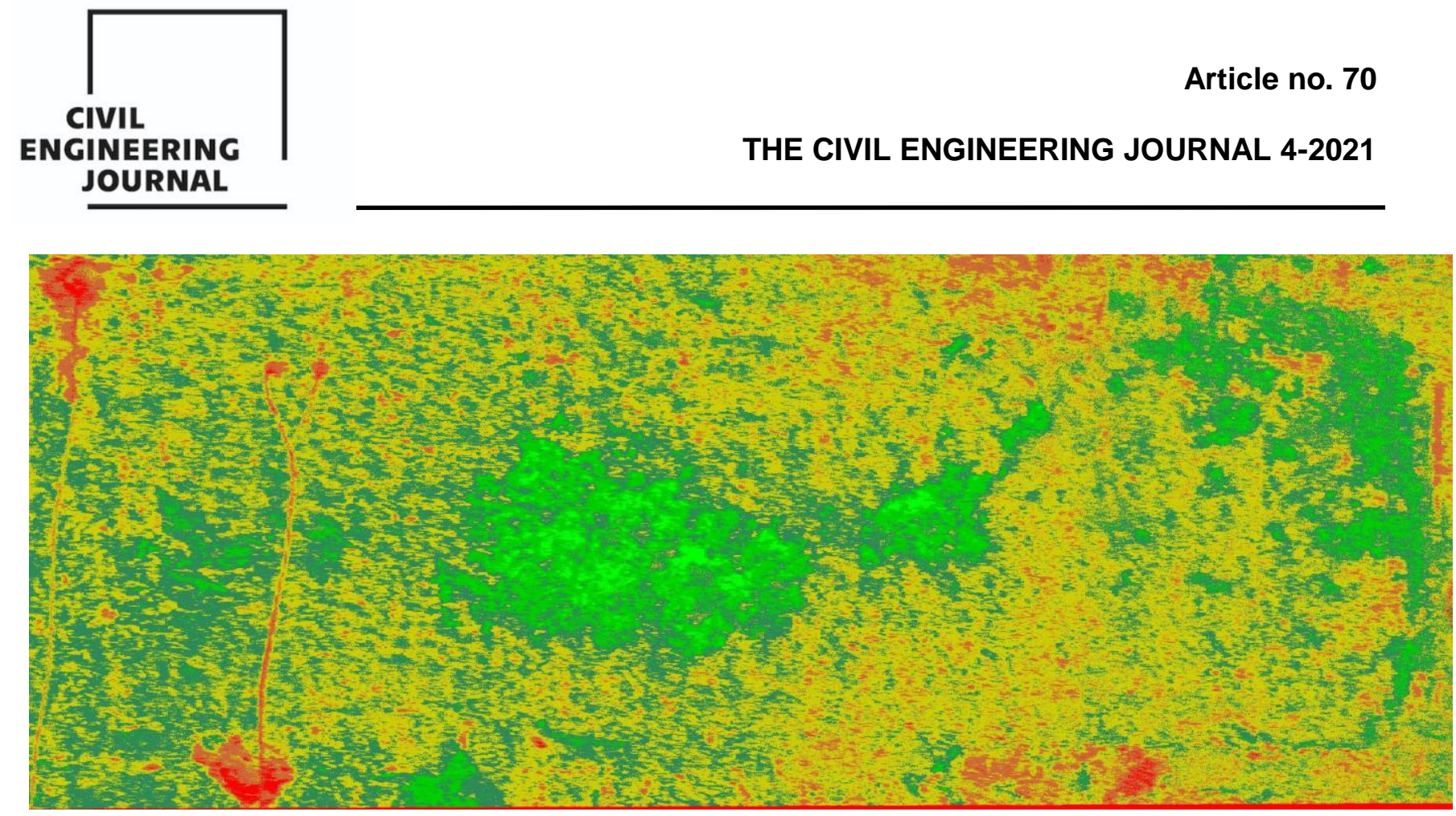

Fig. 6-NDVI image with 6 classes, for legend see Figure GRAF August.

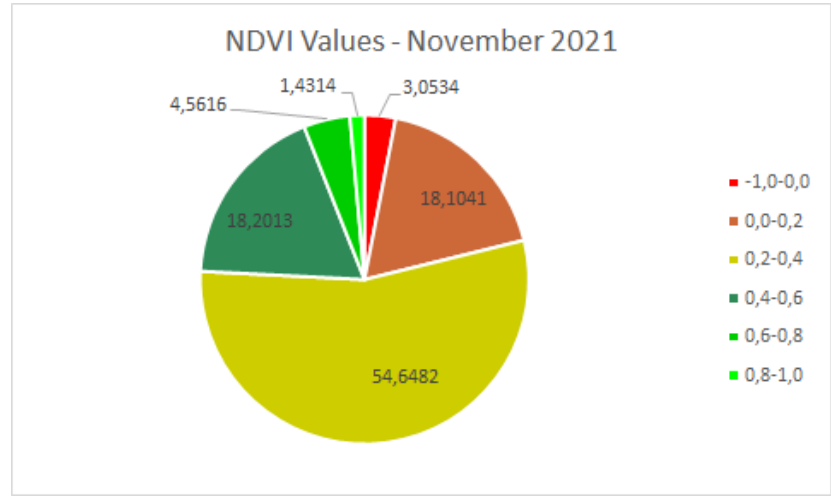

Fig. 7- NDVI Values derived into 6 classes together with percentage of each class.

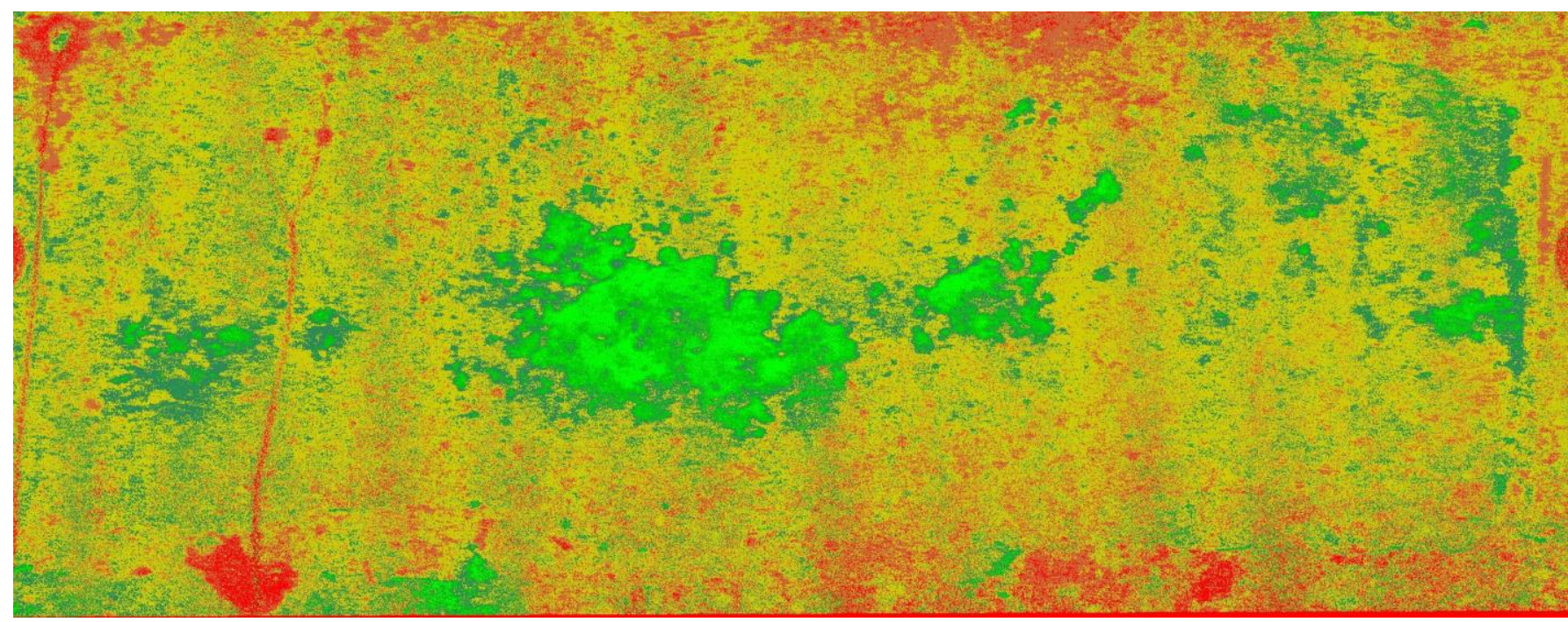

Fig. 8- NDVI image with 6 classes, for legend see Figure GRAF November. 


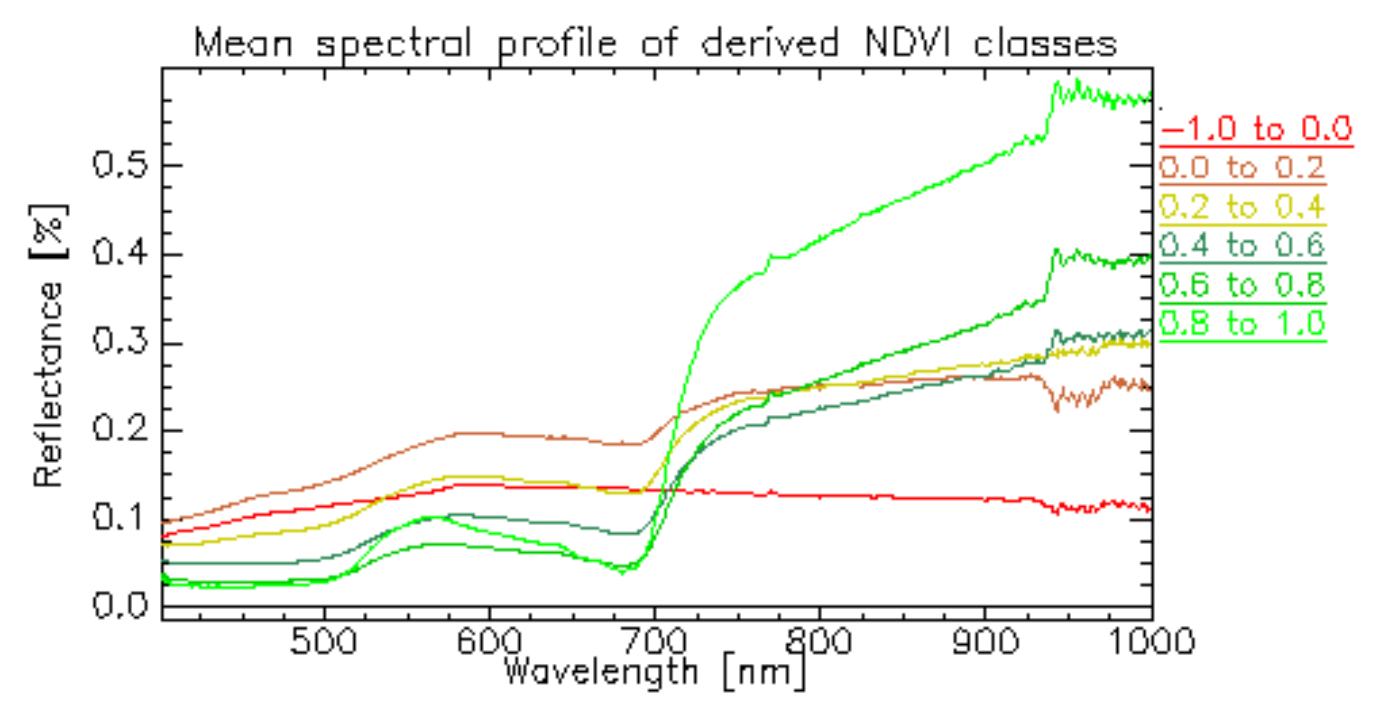

Fig. 9 - Mean spectral signatures of derived NDVI value classes.

\section{CONCLUSION}

A specific historical sandstone sample was chosen for a temporal analysis. Significant changes can be found when summer (August) and autumn (November) measurement were compared (Figures 6 and 8 ). The NDVI value changes between the measurements are summarized in Table 2.

Tab. 2: NDVI value change between November and August measurements.

\begin{tabular}{|c|c|}
\hline Class NDVI value & Change [\%] \\
\hline$-1,0-0,0$ & 2,06 \\
\hline $0,0-0,2$ & 10,25 \\
\hline $0,2-0,4$ & 5,72 \\
\hline $0,4-0,6$ & $-15,60$ \\
\hline $0,6-0,8$ & $-3,05$ \\
\hline $0,8-1,0$ & 0,62 \\
\hline
\end{tabular}

According to the authors assumption the negative value class (red) raised from $1 \%$ to $3 \%$ and class with values from 0 to 0,2 raised from $7,8 \%$ to $18 \%$ so more bare rock is visible in the autumn. Data show approximately $6 \%$ more vegetation in the November image in the 0,2 to 0,4 class with represent low density vegetation that covers almost half of the area of interest. Medium density vegetation (NDVI Value $0,4-0,6$ ) was decreased by $15,6 \%$ and high-density vegetation $(0,6-0,8)$ by more than $3 \%$. The increase of very high-density vegetation is very interested. We assume that this fact may be caused by growing homogeneity of moss towards winter season. The relationship of the moss leaves density and stress action is discussed by some authors. According to Malenovsky et al. [19], optimal growing conditions produce less dense and larger moss leaves, whereas worse growing conditions lead to smaller leaves with higher density.

Moss can hibernate, thanks to their possibilities to dry up, shut down, and go dormant until more suitable conditions return. Cell components of moss can remain intact even when no liquid remains in the cell. Moss leaves are usually only one cell thick, which enabling their rapid cooling 


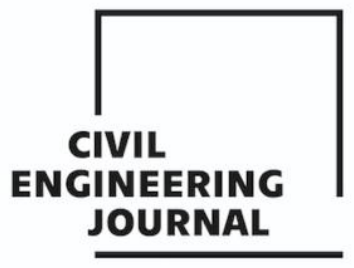

Article no. 70

THE CIVIL ENGINEERING JOURNAL 4-2021

and dehydration. This process lowers the freezing point inside their cells and helps prevent internal crystal formation, which can damage the delicate cell walls [20].

Due to the nature of gained data there are many processing possibilities. With the project ongoing, they will be tested and final results will be published. Finally, the synergy of weathering processes will be also studied and evaluated, but the possibilities of laboratory analysis of stone samples is strongly influenced due to the inability of destructive sampling.

\section{ACKNOWLEDGEMENT}

This paper and corresponding research was conducted by the Czech Ministry of Culture project DG20P02OVV021 "Stone surface topography and its application in stone element restoration field".

\section{REFERENCES}

[1] Březinová D., Bukovanská M., Dudková I., Rybařík V., Praha kamenná, Prírodní kameny v pražských stavbách a uměleckých dílech, Praha, 287 p., 1996.

[2] Goodman R., Introduction to rock mechanics, New York, 562 p., 1989.

[3] R.B.G. Williams, D.A. Robinson, Experimental frost weathering of sandstones by various combinations of salts, Earth Surface Processes and Landforms, 26 (2001) 811-818.

[4] A. Goudie, H. Viles, Salt weathering hazards, John Wiley \& Sons Ltd., Chichester, 1997.

[5] WARSCHEID, Th. a J. BRAAMS. Biodeterioration of stone: a review. International Biodeterioration \& Biodegradation [online]. 2000, 46(4), 343-368 [cit. 2020-08-18]. ISSN 09648305. Dostupné z: doi:10.1016/S0964-8305(00)00109-8

[6] Biologické napadení stavebních materiálů. Izolace.cz [online]. Praha: A.W.A.L. - PRO, s.r.o., 2006 [cit. 2020-08-18]. Dostupné z: https://www.izolace.cz/clanky/biologicke-napadeni-stavebnich-materialu/

[7] ADAN, Olf a Robert SAMSON. Fundamentals of Mold Growth in Indoor Environments and Strategies for Healthy Living. 1. Wageningen: Wageningen Academic Publishers, 2011. ISBN 978-90-8686-722-6.

[8] CANEVA, Giulia a Salvador ORNELLA. Biodeterioration of Stone. The Deterioration and Conservation of Stone: Notes from the International Venetian Courses on Stone Restoration. 1988, , 182-234.

[9] GRIFFIN, P.S., N. INDICTOR a R.J. KOESTLER. The Biodeterioration of Stone: a Review of Deterioration Mechanisms, Conservation Case Histories, and Treatment. International Biodeterioration [online]. 1991, 28(1), 187-207 [cit. 2020-08-18]. Dostupné z: doi:10.1016/0265-3036(91)90042-P

[10] MARTÍNEZ-MARTÍNEZ, Javier, David BENAVENTE, Miguel GOMEZ-HERAS, Luz MARCOCASTAñO a M. GARCÍA-DEL-CURA. Non-linear decay of building stones during freeze-thaw weathering processes. Construction and Building Materials [online]. 2013, 38, 443-454 [cit. 2020-08-18]. ISSN 09500618. Dostupné z: doi:10.1016/j.conbuildmat.2012.07.059

[11] MCNAMARA, Christopher a Ralph MITCHELL. Microbial deterioration of historic stone. Frontiers in Ecology and the Environment [online]. 2005, 3(8), 445-451 [cit. 2020-08-18]. ISSN 1540-9295. Dostupné z: doi:10.1890/1540-9295(2005)003[0445:MDOHS]2.0.CO;2

[12] SCHEERER, Stefanie, Otto ORTEGA - MORALES a Christine GAYLARDE. Chapter 5 Microbial Deterioration of Stone Monuments-An Updated Overview [online]. Elsevier, 2009, , 97-139 [cit. 2020-08-18]. Advances in Applied Microbiology. ISBN 9780123747884. Dostupné z: doi:10.1016/S0065-2164(08)00805-8 [13] SMITH, B.J., M. GOMEZ-HERAS a S. MCCABE. Understanding the decay of stone-built cultural heritage. Progress in Physical Geography: Earth and Environment [online]. 2008, 32(4), 439-461 [cit. $2020-$ 08-18]. ISSN 0309-1333. Dostupné z: doi:10.1177/0309133308098119

[14] WELTON, , RYAN G, Simon CUTHBERT, Roger MCLEAN, Andrew HURSTHOUSE a John HUGES. A Preliminary Study of the Phycological Degradation of Natural Stone Masonry. Environmental Geochemistry and Health. 2003, 25(1), 139-45.

[15] PODLISKA J., SEMERÁD M. Nové poznatky o konstrukci Juditina mostu v Praze. Staletá Praha, 28(2), 2012, dostupné: http://www.staletapraha.cz/media/2012_2/clanky-cele/sp-2-2012-08-podliskasemerad.pdf 
[16] Hyperspectral sensors. Headwall Photonics [online]. USA: Headwall Photonics, 2020 [cit. 2020-0825]. Dostupné Z: https://www.headwallphotonics.com/hyperspectral-sensors

[17] HUETE, A.R. a R.D. JACKSON. Soil and atmosphere influences on the spectra of partial canopies. Remote Sensing of Environment [online]. 1988, 25(1), 89-105 [cit. 2021-12-17]. ISSN 00344257. Dostupné z: doi:10.1016/0034-4257(88)90043-0

[18] ENVI Classic. ENVI Classic help [online]. Harris Geospatial Solutions, 2019 [cit. 2021-12-17]. Dostupné

file://C:/Program\%20Files/Harris/ENVI55/classic/help/ENVI3WHelp.htm\#ENVI3WHome.htm\%3FTocPath\%3 DGetting\%2520Started\%7C 0

[19] MALENOVSKY Z., TURNBULL JD., LUCIEER A., ROBINSON SA. Antarctic moss stress assessment based on chlorophyll content and leaf density retrieved from imaging spectroscopy data. New phytologist. 2015, 208(2), 608-624, ISSN 0028-646X.

[20] ILLERBRUN K. Antifreeze and sunblock: How mosses survive an Alberta winter, 2021, available online: http://blog.abmi.ca/2021/11/29/antifreeze-and-sunblock-how-mosses-survive-an-alberta-winter/ 